\begin{tabular}{|c|c|c|}
\hline 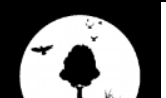 & Our Natur & $\begin{array}{l}\text { ISSN: 1991-2951 (Print) } \\
\text { ISSN: 2091-2781 (Online) }\end{array}$ \\
\hline $\begin{array}{l}\text { Nature Conservation \& } \\
\text { Health Care Councill } \\
\text { Brratnogar Nopal }\end{array}$ & 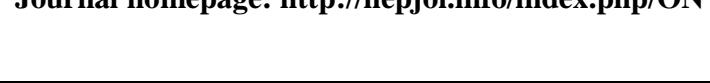 & $\underbrace{}_{\mathrm{BY}}$ \\
\hline
\end{tabular}

\title{
Investigation on impacts of artisanal refining of crude oil on river bed sediments
}

\author{
I.C. Howard ${ }^{1 *}$, O.D. Azuatola ${ }^{1}$ and I.K. Abiodun ${ }^{2}$ \\ ${ }^{1}$ Department of Chemistry/Biochemistry, Federal Polytechnic, Nekede, Owerri. Imo State, Nigeria \\ ${ }^{2}$ Department of Biochemistry/Microbiology' Federal Polytechnic, Nekede, Owerri. Imo State, Nigeria \\ *E-mail: dromiete_ib@yahoo.com
}

\begin{abstract}
The impact of artisanal refining of crude oil on the river bed sediments of the study area was investigated by assessing some quality properties. The result showed some consistency across the stations of the study area; however there were some differences between the values of the test stations and control station indicating some level of impacts on the quality of the sediments. The mean values of the test stations are $\mathrm{pH}$ $3.3 \pm 0.7$, E. conductivity $-10.2 \pm 3.7 \mathrm{mS} / \mathrm{cm}$, Salinity $19.0 \pm 4.0 \%$ o, $\mathrm{PO}_{4}{ }^{3-} 401.8 \pm 67.0$ $\mathrm{mg} / \mathrm{kg}, \mathrm{SO}_{4}{ }^{2-} 279.8 \pm 52.8 \mathrm{mg} / \mathrm{kg}, \mathrm{NO}^{3-} 58.0 \pm 22.9 \mathrm{mg} / \mathrm{kg}, \mathrm{SO}_{2} 215 \pm 100.2 \mathrm{mg} / \mathrm{kg}, \mathrm{Cl}^{-}$ $97.4 \pm 89.8 \mathrm{mg} / \mathrm{kg}$, TOM $45.6 \pm 51.4 \%, \mathrm{~K}^{+} 1.054 \pm 0.3 \mathrm{meq} / 100 \mathrm{~g}, \mathrm{Na}^{+} 6.385 \pm 2.5$ meq $/ 100 \mathrm{~g}$ and $\mathrm{Ca}^{2+} 0.756 \pm 0.6 \mathrm{meq} / 100 \mathrm{~g}$ while that of the control values are $4.15 \pm 0.55$, $11.0 \pm 0.0,12.2 \pm 0.6,428.25 \pm 12.75,294.9 \pm 8.2,76.8 \pm 15.2,148.75 \pm 23.75,126 \pm 99,20$. $9 \pm 4.1,0.798 \pm 0.34,5.639 \pm 1.383$ and $0.261 \pm 0.128$, respectively. The result indicated that the said activities affected the $\mathrm{pH}, \mathrm{PO}_{4}{ }^{3-}, \mathrm{SO}_{4}{ }^{2-}, \mathrm{NO}^{3-}, \mathrm{Cl}^{-}$etc. of the study area; as these values were consistently lower than that of the control station. Again some of the quality properties were higher or lower than those of the control station and some related studies within and outside the region of the study area indicating some impacts which could be mostly anthropogenic. These impacts if not checked and the makeshift refining of the crude oil stopped by the appropriate regulatory bodies could have some adverse effects on the aquatic life quality of the ecosystem.
\end{abstract}

Key words: Anthropogenic, Aquatic life, Salinity, Conductivity, Quality of sediments

DOI: http://dx.doi.org/10.3126/on.v15i1-2.18792

Manuscript details: Received: 17.04.2017 / Accepted: 04.11.2017

Citation: Howard, I.C., O.D. Azuatola and I.K. Abiodun 2017. Investigation on impacts of artisanal refining of crude oil on river bed sediments. Our Nature 15(1-2): 34-43. DOI: http://dx.doi.org/10.3126/on.v15i1-2.18792

Copyright: (C) Howard et al., 2017. Creative Commons Attribution - Non Commercial 4.0 International License.

\section{Introduction}

It is a known fact that the livelihoods of the people of the Niger Delta region of Nigeria depends largely, and almost solely on the aquatic resources of their coastal environment, (Ibigoni et al., 2009; UNEP, 2011; Akporido and Asagba, 2013). History has it that years back, before the era of oil boom in the region, yields from farming, and catches from fishing expedition, were so bountiful and markedly high making exportation imperative, but today reverse is the case, very poor harvest, and scanty or no catch characterized agricultural activities in the creeks and hard patches of the region (Howard, 2004). This trend, most researchers in environmental studies strongly attribute to high level of contamination of the aquatic and terrestrial ecosystems owing to oil exploration/ exploitation in the region (Osuji and Ezeburio, 2006; Ibigoni et al., 2009; UNEP, 2011; Karbassi et al., 2015).

The most recent development and worriso- 
me to environmentalist is the issue of pipeline vandalism, oil scooping, illegal bunkering and refining of crude oil (make-shift refineries) and consequent spill into, and damage of the environment. Given crude methods, lack of expertise and technical know-how, perpetrators of oil pipeline sabotage often spill large quantities of oil into the environment-causing great harm to man, plants, animals, and the totality of local and distant biota. This single act of sabotage has further plundered and depleted the aquatic resource base, thereby reducing the ability of locals to make/earn a living from this (aquatic) resource base.

Whenever there is a crude oil spillage some of the spilled oil sinks to the bottom of the riverbed and permeates into the bottom sediment. Most of these oils that sinks are hydrophobic, hence they find firm hold in bottom sediments which is home to most breeding fin and shell fishes, and provides the bulk of nutrients to the phytoplankton needed to sustain the food chain of aquatic ecosystems, and to a large extent, determine the physiochemical characteristics of the river or creek; as well as regulate the natural cycles of all its components/constituents (Abowei and Sikoki, 2005). The resultant effects of the above are a change in desirable portable water characteristics (Ibigoni et al., 2009); impaired growth of marine organisms which depend basically on the quantity and quality of the primary production of phytoplankton, fish, crustaceans and molluscs acquire objectionable odour or flavour, thereby causing a reduction in their marketability and acceptance as food (Ibigoni et al., 2009; Briggs,
2010; Howard et al., 2012). Death of the fauna and flora from oil spills is common place in the Niger Delta region of Nigeria where the most intensive oil exploration; exploitation and refining occur (Ibigoni et al., 2009; UNEP, 2011). Besides, oil contamination of coastal amenities has adverse effects on tourism, recreation and aesthetics of the impacted area. This effect can be substantial on a community whose economy depends on tourism (UNEP, 2011). It is against this background that the level of impact of these activities on some quality parameters of the river bed sediments of the study area where artisanal refining of crude oil was carried out in 2012 to 2013.

\section{Study area}

The study area which is closed to the make shift crude oil refining area (source point) is located at the South-West fringe of the Andoni Local Government Area, Rivers State, precisely between Long. $7^{\circ} 20^{\prime} 48.639^{\prime \prime} \mathrm{E}$ and Lat. $4^{\circ} 29^{\prime}$ $20.169^{\prime \prime} \mathrm{N}$. The River is tidal in nature and drains the adjoining mangrove on both sides; it empties into the Andoni River (Okwaan Obolo), one of the major rivers draining the Eastern Niger Delta into the Atlantic Ocean. Generally, the area is low-lying; it is about $5 \mathrm{~m}$ above sea level. The area is typical of the Niger Delta ecosystem that is supported by saline soil with potential of Hydrogen $(\mathrm{pH})$ value of between 4 for freshly deposited soft silt low tide and 7 for transitional swamps at high tide. Six sampling stations (SSA, SSB, SSC, SSD, SSE and SSF) hereafter referred to as A, B, C, D, E and F was chosen within the study area (Fig. 1).

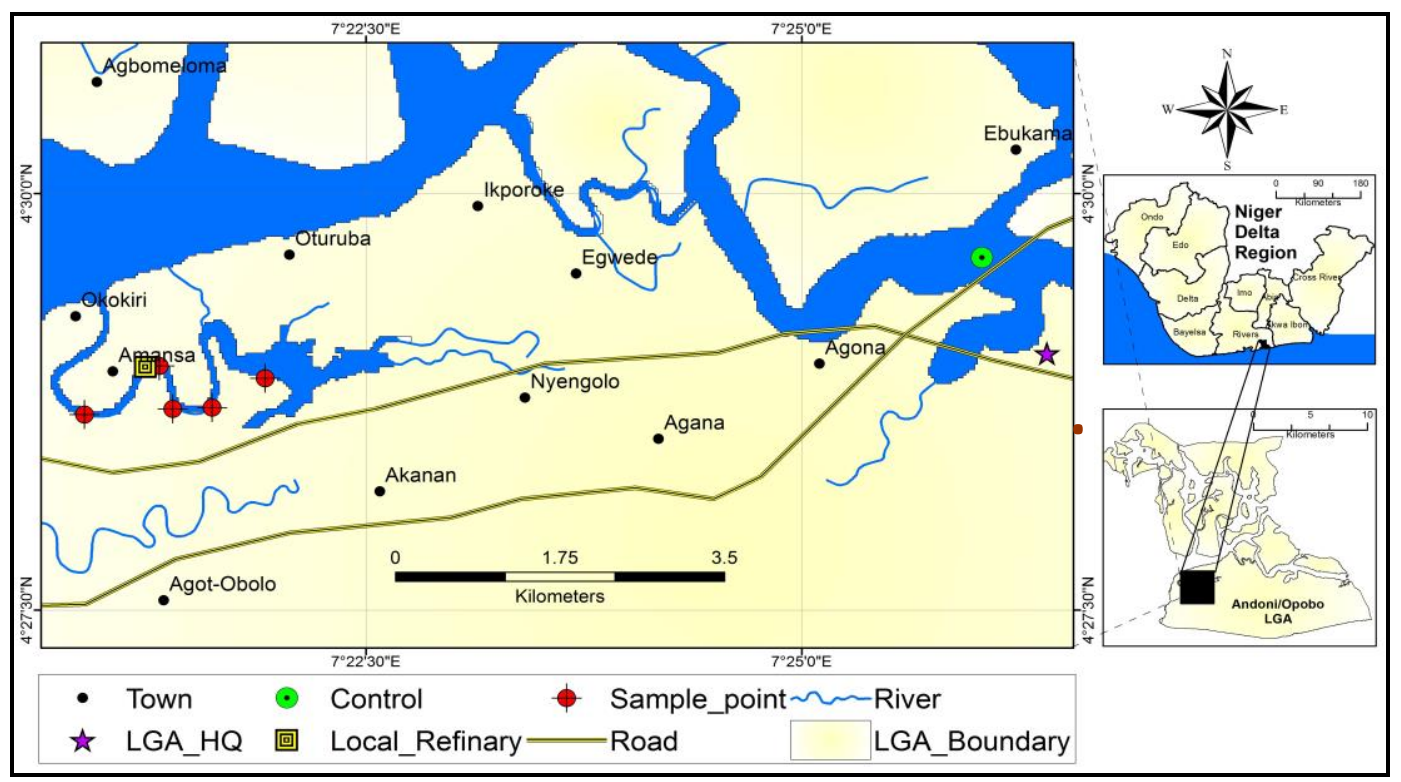

Figure 1. Map of the study area showing sample stations. 
The first sampling station (SSA) is located some kilometres away-upstream from the source point (SSC) with GPS coordinates $7^{\circ} 21^{\prime} 53.592^{\prime \prime}$ $\mathrm{E}$ and $4^{\circ} 28^{\prime} 50.374^{\prime \prime} \mathrm{N}$. Mangrove plant species here is densely populated with sights of crabs, mudskipper, periwinkles and birds. The surface mud at this station was normal-not stained with oil, but careful observation could reveal very thin oil sheen on the surface of the river at this station. The second sample station (SSB) lies within $7^{\circ} 21^{\prime} 37.046^{\prime \prime} \mathrm{E}$ and $4^{\circ} 28^{\prime} 42.957^{\prime \prime} \mathrm{N}$. Oil sheen was seen on the surface of the river, especially during low tide. Mangrove plants were sparsely dense with dotted aquatic fauna such as juvenile periwinkle, crabs, mudskipper, etc. in the mangrove mudflats. The mud here is oil-stained as in SSA above, but no direct inlet of spilled oil into the water body was observed.

Sample station $\mathrm{C}$ is the source point where the raw crude oil and some crudely refined products find their way into the river-either via surface run-off or seepage whenever there was a large spill. It is within $7^{\circ} 21^{\prime} 23.353^{\prime \prime} \mathrm{E}$ and $4^{\circ} 28^{\prime}$ $50.945^{\prime \prime} \mathrm{N}$. The surface mud here is darkened from oil stain and greasy, with scanty mangrove plants, withered leaves, prop roots and stems. No aquatic organism was spotted as oil sheen was seen on the surface of river water and the adjourning mudflats.

Sample station (SSD) is located downstream from SSC with GPS coordinates $7^{\circ} 21^{\prime}$ $13.654^{\prime \prime} \mathrm{E}$ and $4^{\circ} 28^{\prime} 38.963^{\prime \prime} \mathrm{N}$. Oil sheen was seen on the surface of the river, surface sediments at both side are badly oil-stained as aquatic fauna and flora are very scanty and unhealthy. Sample station E (SSE) is downstream from SSA, with GPS coordinates $7^{\circ} 20^{\prime}$ $53.685^{\prime \prime} \mathrm{E}$ and $4^{\circ} 28^{\prime} 40.675^{\prime \prime} \mathrm{N}$. This station has relatively buoyant aquatic flora and fauna; which can be attributed to its location which is almost at the mouth of the $3.66 \mathrm{~km}$ river vis-àvis its interaction with fresh and relatively uncontaminated water from the larger Andoni River which drains this point first. Oil sheen is seen on the surface of the river water at this station only during ebb tide.

A sample station (SSF) was chosen as control point at an unimpacted Creek which is far away from the test stations in the same Local Government Area, specifically around the Ngo axis, the mangrove at this station is dense and green with an abundance of aquatic fauna (crabs, periwinkles, mudskippers, birds, reptiles and other aquatic invertebrates). The mangrove mud here is not stained with oil and oil sheen was not seen on the surface of the water here.

\section{Materials and methods}

River bed sediment samples were collected with the aid of a bottom sediment grabber according to the method of Ezekiel et al. (2011). The samples were then put into sterilized bottles and stored in the sample chest with ice, thereafter, transported to the laboratory, same day. Each sample was concurrently collected in triplicates from three different points in each station in the month of July 2012 and February 2013. Immediately after collection, samples were transported in labelled sample containers to the laboratory. A composite mixture was made for each set of samples and out of it a portion was weighed to obtain wet weight, and then sundried for 72 hours and the dry wet obtained too. The dried samples were then macerated into a powdery form and sieved with a $1.0 \mathrm{~mm}$ sieve. The sieved samples were stored in well-labelled smaller plastic containers with cover, from where samples were withdrawn for physicochemical analysis.

Fifty gram of sediment was diluted with $100 \mathrm{ml}$ of distilled water in a $250 \mathrm{ml}$ beaker to produce a ratio of 1:2 mixture (Sawant et el., 2011). This was stirred with a stirring glass rod to homogenize the mixture and then left for 30 minutes to settle. After which, the probes of precalibrated $\mathrm{pH}$, salinity and conductivity meters (Palintest/Wagtech Models) were inserted into the mixture and their respective readings recorded. The anions were analyzed according to the method of Ezekiel et al., (2011) and Ado et al. (2011). For instance nitrates, sulphates, phosphates, chlorides and silica in the sediment were analyzed using APHA 4500- $\mathrm{NO}_{3}{ }^{-} \mathrm{B}$, APHA 4500- $\mathrm{SO}_{4}{ }^{2-} \mathrm{B}$ and APHA $4500-\mathrm{PC}$, APHA 4500-Cl ${ }^{-}$B and APHA $4500-\mathrm{SiO}_{2} \mathrm{C}$ of APHA (2005). $10 \mathrm{ml}$ of sediment solution was transferred into sample cuvette. To this was added the contents of reagent Palintest tablets; whether for the nitrates, sulphates, phosphates and chlorides and silica to complex the colors, if any of the nutrients were present in the sample. The readings were taken on the Palintest/ Wagtech 7100 photometer. Each of the cations was analysed using atomic absorption spectrophotometric method (APHA, 2005).

Total organic matter (TOM) was determined by first determining the total organic carbon and multiplying it by a factor (1.729) using the Walkey - Black method of APHA (2005). This 
method is based on the theory that the colour of a soil sample determines the organic carbon content of that soil. $1 \mathrm{~g}$ of sediment samples was sieved through a $1.0 \mathrm{~mm}$ mesh-size sieve and weighed into $250 \mathrm{ml}$ conical flask. $10 \mathrm{ml}$ of potassium dichromate $\left(\mathrm{K}_{2} \mathrm{Cr}_{2} \mathrm{O}_{7}\right)$ and $20 \mathrm{ml}$ $\mathrm{H}_{2} \mathrm{SO}_{4}$ were added and left to stand for $30 \mathrm{~min}$ on asbestos after intermittent swirls. $100 \mathrm{ml}$ of distilled water (spectator ion) was added. To this was added 3-4 drops of ferrous indicator and titrated with $0.5 \mathrm{~N} \mathrm{FeSO} 4.7 \mathrm{H}_{2} \mathrm{O}$. If the sediment sample is rich in organic carbon it will assume a greenish cast on adding all reagents and indicators but if it is not rich in organic carbon it will assume an orange colour. Upon titration, an organic carbon rich sediment goes from green to light green and finally to maroon red or brown; that is the end point. A blank titration (without $1 \mathrm{~g}$ of sediment) was thereafter carried out and percent TOC was calculated as:

$$
\begin{aligned}
& \% \text { TOC }=\frac{\text { Blank Titre }- \text { Sample Titre } \times 0.003 \times 100}{\text { Sampleweight }} \\
& \% \text { TOM }=\% \text { TOC } \times 1.729
\end{aligned}
$$

All statistical analysis was carried out with the aid of Data Analysis Toolpak in Microsoft office Excell $2003^{\circ}$ and SPSS. Differences in the levels of the properties were separated by Duncan Multiple Range Test (DMRT) at 95\% level of probability.

\section{Results and discussion}

The mean concentrations of the physical and chemical properties in the river bed sediments of the study area in comparison to those of the control station and a summary of the statistical analysis of the data are as follows (Table 1).

The seasonal mean variations of the quality parameters/properties of the river bed sediments of the study area in comparison to those of the control station, respectively (Figs. 2, 3) showed that conductivity, salinity, sulphate, total organic carbon, potassium, sodium and Calcium are higher than those of the control values. Of all the parameters studied, it was only total organic matter that had significant variation $(\mathrm{P}<0.05)$ among the stations. Seasonally, the dry season's values of conductivity, salinity, phosphate, sulphate, silicate, chloride, sodium ions and total nitrogen were all significantly different $(\mathrm{P}<$ 0.05 ) from those of the wet season (Fig. 4). The impact of the activities of the artisanal refining of five stations (using the quality parameters) that are directly close to it were compared with those of the control station (Fig. 5).

The hydrogen ion concentration $(\mathrm{pH})$ in river bed sediments of the study area was stable across the test stations as there were no significant difference between the stations (Table 1) though they were all acidic. Comparatively, the mean $\mathrm{pH}$ of the sediment of the test stations is more acidic $(3.3 \pm 0.7)$ than the control $(4.15 \pm 0.55)$. The most acidic station is station B which is $500 \mathrm{~m}$ upstream away from the source station. The low value of $\mathrm{pH}$ indicating acidic condition in the sediments may be due to the oxidation of $\mathrm{FeSO}_{4}$ and $\mathrm{FeS}$ to $\mathrm{H}_{2} \mathrm{SO}_{4}$ (Masoud et al., 2005). In addition, soil acidity may have resulted also from decomposition of mangrove litter. $\mathrm{pH}$ is an important attribute of sediments/soils because it affects the solubilities of the various ionic species, the bonding of the ions to exchange sites and microbial activity in the soil (Babatunde and Ajibola 2009; Karbassi and Heidari 2015). In moderately neutral to strongly acidic soils for instance, phosphates becomes less available through interactions with $\mathrm{Fe}(\mathrm{OH})_{3}$

Table 1. The physical and chemical characteristics of the surface water and sediments of the study area

\begin{tabular}{lccccccc}
\hline Quality & \multicolumn{7}{c}{ Stations } \\
\cline { 2 - 7 } Parameters & SSA & SSB & SSC & SSD & SSE & MEAN \pm Std Control SSF \\
\hline $\mathrm{pH}$ & $3.2 \pm 0.2$ & $2.5 \pm 0.4$ & $3.8 \pm 0.8$ & $3.1 \pm 0.4$ & $3.0 \pm 0.8$ & $3.3 \pm 0.7$ & $4.15 \pm 0.55$ \\
E.Cond. $(\mathrm{mS} / \mathrm{cm})$ & $10.2 \pm 1.1$ & $14.2 \pm 2.7$ & $8.4 \pm 4.1$ & $10.3 \pm 4$ & $16.1 \pm 4.7$ & $10.2 \pm 3.7$ & $11.0 \pm 0.0$ \\
Salinity $(\% \mathrm{o})$ & $18.0 \pm 1.0$ & $16.0 \pm 3.0$ & $20.0 \pm 8.0$ & $18.0 \pm 5.0$ & $20.0 \pm 7.0$ & $19.0 \pm 4.0$ & $12.2 \pm 0.6$ \\
$\mathrm{PO}_{4}{ }^{3-}(\mathrm{mg} / \mathrm{kg})$ & $418.8 \pm 48.6$ & $410.8 \pm 64.0$ & $425.6 \pm 56.6$ & $347.8 \pm 53.5$ & $406.6 \pm 114.5$ & $401.8 \pm 67.0$ & $428.25 \pm 12.75$ \\
$\mathrm{SO}_{4}{ }^{2-}(\mathrm{mg} / \mathrm{kg})$ & $274.5 \pm 50.1$ & $294.0 \pm 26.2$ & $280.0 \pm 64.3$ & $247.1 \pm 41.6$ & $303.6 \pm 69.2$ & $279.8 \pm 52.8$ & $294.9 \pm 8.2$ \\
$\mathrm{NO}_{3}{ }^{-}(\mathrm{mg} / \mathrm{kg})$ & $45.3 \pm 3.7$ & $37.7 \pm 6.6$ & $44.8 \pm 1.1$ & $79.6 \pm 6.8$ & $82.8 \pm 30.0$ & $58.0 \pm 22.9$ & $76.8 \pm 15.2$ \\
$\mathrm{SO}_{2}(\mathrm{mg} / \mathrm{kg})$ & $262.5 \pm 77.8$ & $211.0 \pm 199.4$ & $196.3 \pm 76.0$ & $190.0 \pm 53.0$ & $217.5 \pm 106.1$ & $215 \pm 100.2$ & $148.75 \pm 23.75$ \\
$\mathrm{Cl}^{-}(\mathrm{mg} / \mathrm{kg})$ & $99.5 \pm 60.5$ & $98.8 \pm 122.0$ & $111.3 \pm 132.6$ & $90.3 \pm 112.8$ & $87.3 \pm 110.0$ & $97.4 \pm 89.8$ & $126 \pm 99$ \\
$\mathrm{TOM}(\%)$ & $16.0 \pm 3.7$ & $29.1 \pm 3.7$ & $16.2 \pm 2.8$ & $142.2 \pm 9.6$ & $24.5 \pm 5.6$ & $45.6 \pm 51.4$ & $20.9 \pm 4.1$ \\
$\mathrm{~K}^{+}(\mathrm{meq} / 100 \mathrm{~g})$ & $1.4 \pm 0.1$ & $0.8 \pm 0.3$ & $1.0 \pm 0.4$ & $1.2 \pm 0.1$ & $0.9 \pm 0.3$ & $1.054 \pm 0.3$ & $0.798 \pm 0.34$ \\
$\mathrm{Na}^{+}(\mathrm{meq} / 100 \mathrm{~g})$ & $6.7 \pm 1.9$ & $5.0 \pm 3.7$ & $7.0 \pm 1.7$ & $7.9 \pm 0.5$ & $5.3 \pm 3.9$ & $6.385 \pm 2.5$ & $5.639 \pm 1.383$ \\
$\mathrm{Ca}^{2+}(\mathrm{meq} / 100 \mathrm{~g})$ & $0.5 \pm 0.0$ & $0.8 \pm 0.8$ & $1.6 \pm 0.7$ & $0.5 \pm 0.5$ & $0.5 \pm 0.4$ & $0.756 \pm 0.6$ & $0.261 \pm 0.128$ \\
\hline
\end{tabular}




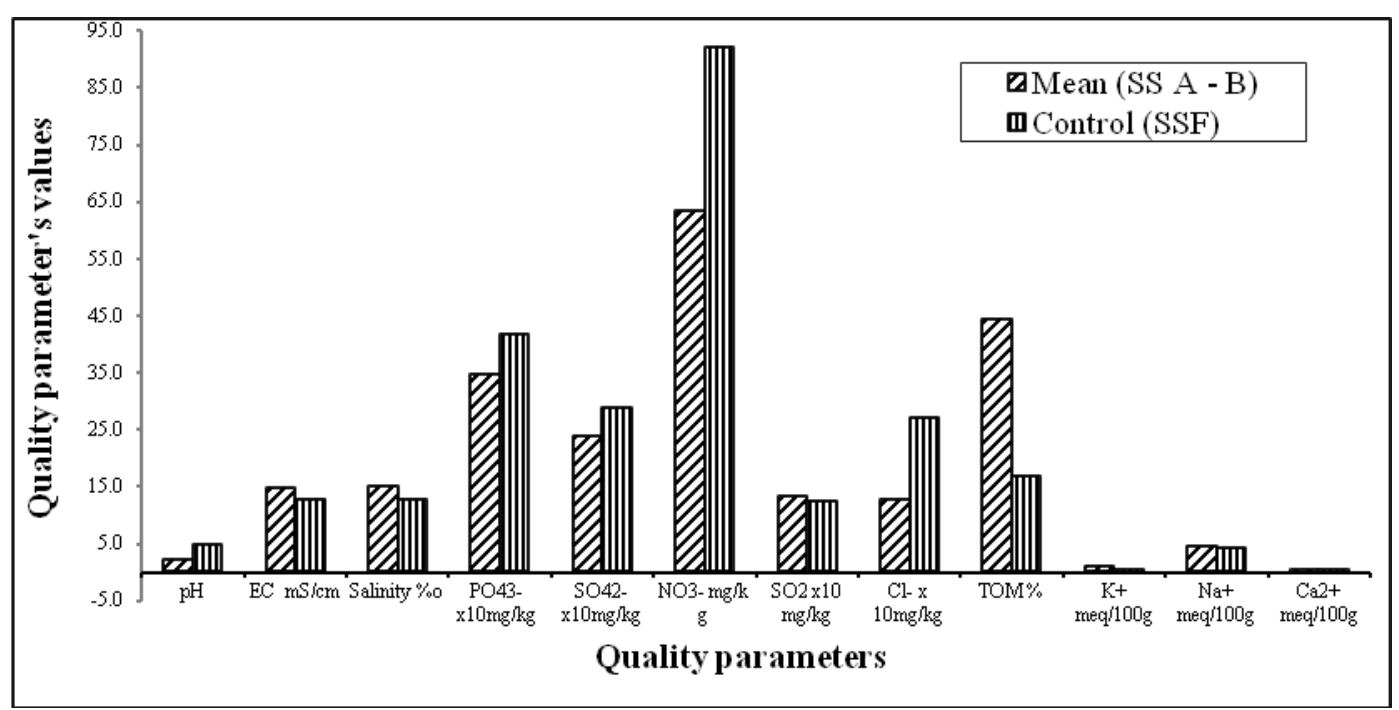

Figure 2. Comparison of the quality parameters of the test stations and control station of the study area for the wet season.

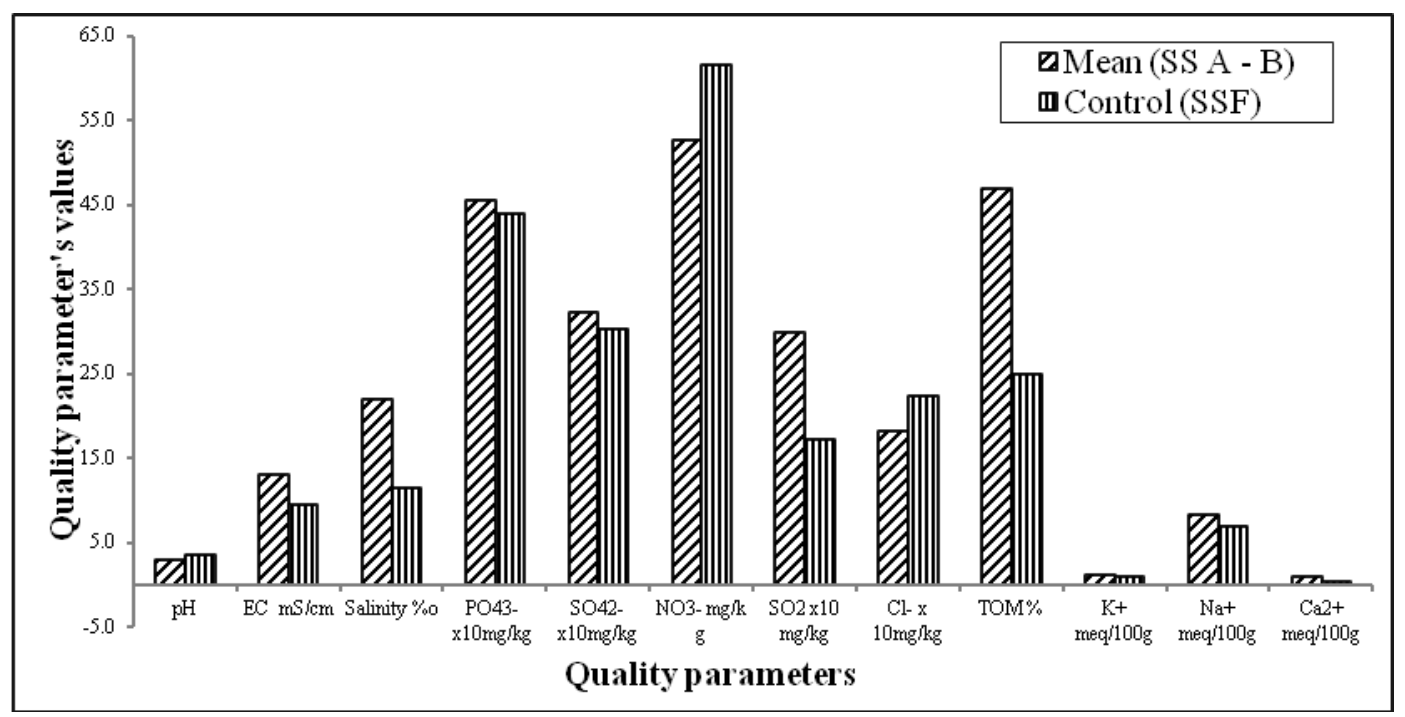

Figure 3. Comparison of the quality parameters of the test stations and control station of the study area for the dry season.

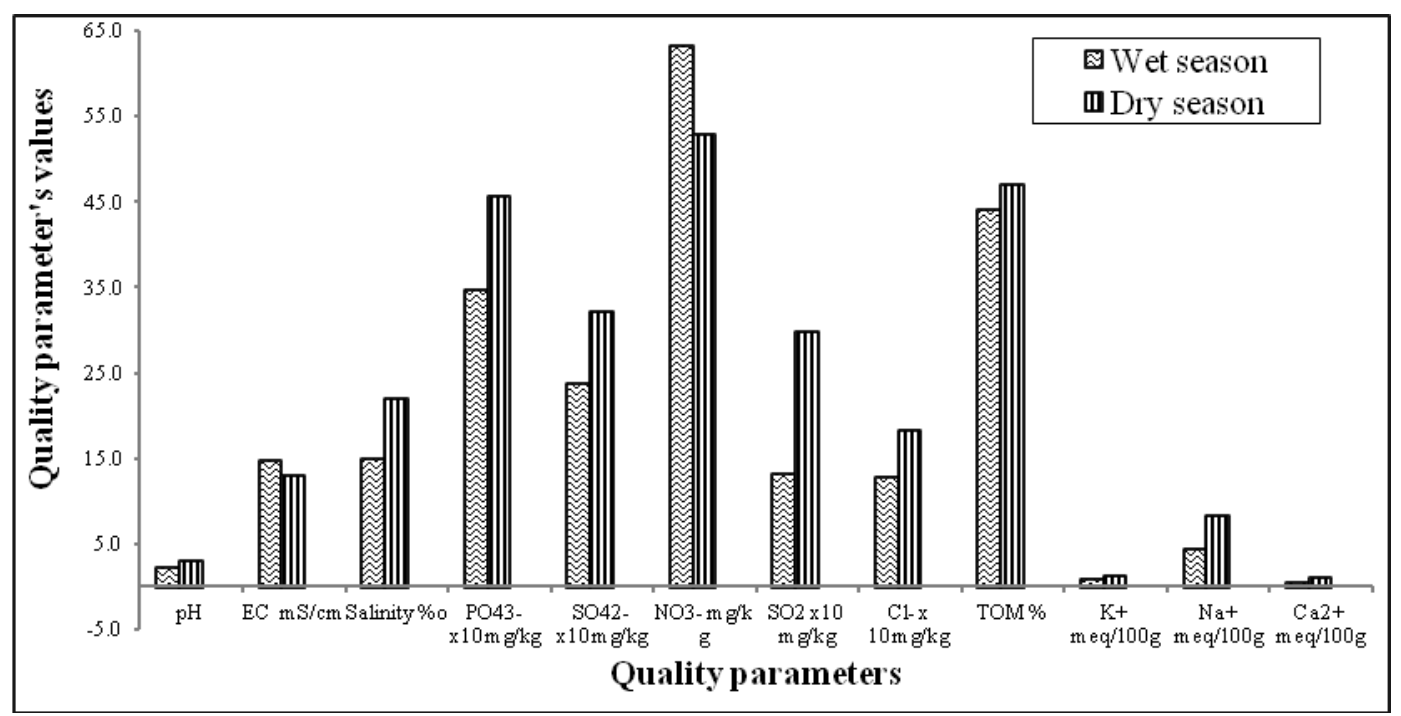

Figure 4. Seasonal variation of the quality parameters in the sediments of the study area. 


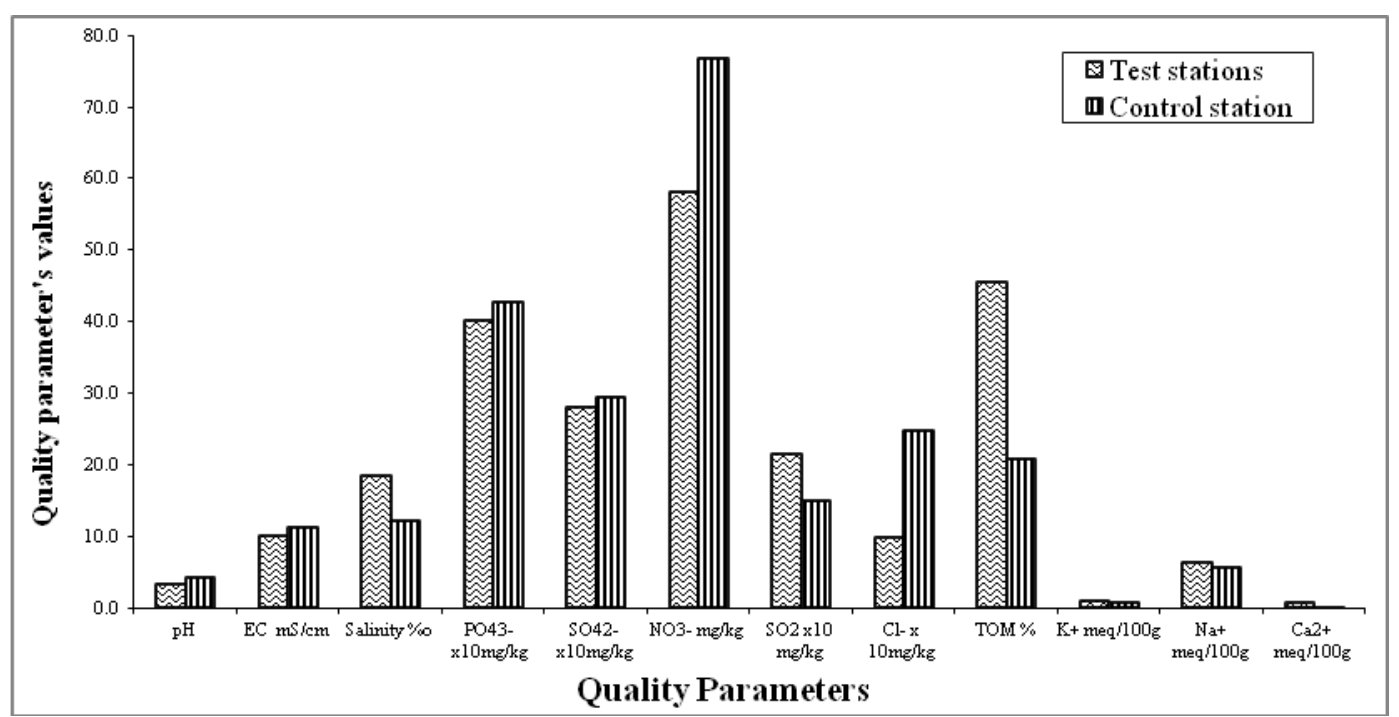

Figure 5. Variation of quality parameters in the riverbed sediments of the study area.

and $\mathrm{Al}(\mathrm{OH})_{3}$. At high $\mathrm{pH}$, phosphates become increasingly insoluble because of their interactions with $\mathrm{Ca}^{2+}$ to form apatite and other precipitates (Babatunde and Ajibola 2009). The mean value $(3.3 \pm 0.7)$ of the sediment $\mathrm{pH}$ obtained in this study is lower than that reported by Ezekiel et al. (2011) (5.59) from the sediments of Sombriero river, Niger Delta; Ebere (2002) (4.27 - 4.88) of Okirika creek sediment; Davies and Abowei (2009) (5.22 \pm 0.27 ) in the sediment of Okpoka creek Niger Delta, Sewant et al. (2011) (7.5) from Tapti river sediments, and Saravanakumar et al. (2008) (7.6) in the mangroves of Kachchh-Gujarat where there were no hydrocarbon activities. It is also lower than that reported $(5.1 \pm 0.1)$ by Osuji and Ezeburio (2006) where there was hydrocarbon contamination.

The mean electrical conductivity values of the stations varied from $8.4 \pm 4.1 \mathrm{mS} / \mathrm{cm}$ (Station C) to $16.1 \pm 4.7 \mathrm{mS} / \mathrm{cm}$ (Station E), whereas the mean value is $10.2 \pm 3.7 \mathrm{mS} / \mathrm{cm}$ and is less than that of the control station $(11.0 \pm 0.0 \mathrm{mS} / \mathrm{cm})$. The higher mean value of the control station could be the normal values of the area but some activities that are going on within the test stations could have disrupted the conductivity values. Station E's value is higher than all the stations values as it is closer to the main Andoni River that links up to the Atlantic Ocean. The mean conductivity of the stations was higher than those of the control for both the wet and dry season (Figs. 2, 3). On a general note the wet season's value is higher than that of the dry season which is in conformity that reported by Ezekiel et al. (2011). The mean conductivity value of this study is higher than that reported by
Osuji and Onojake (2004) $(2.8 \pm 0.4 \mathrm{mS} / \mathrm{cm})$ in an oil spill site, Ezekiel et al. (2011) (0.53 $\mathrm{mS} / \mathrm{cm})$, Braide et al. (2004) $(0.1-0.23 \mathrm{mS} / \mathrm{cm})$, Davies and Abowei (2009) $(5.1 \pm 0.85 \mathrm{mS} / \mathrm{cm})$ and Sawant et al. (2011) $(3.8 \mathrm{mS} / \mathrm{cm})$.

The mean Salinity of the study area ranged from $16.0 \pm 3.0 \%$ (Station B) to $20.0 \pm 8.0 \%$ (Station C and E) and the mean value is $19.0 \pm$ 4.0 that is higher than that of the control station $(12.2 \pm 0.6 \%$ on $)$ unlike the conductivity the mean value of the test stations is higher than the control, this might be due to the fact that the test stations are further down the downstream, that is towards the Atlantic ocean than that of the control station. The values are all higher in both seasons in the test stations than in the control station. Seasonal, salinity values in this study are higher in the dry season than in the wet season. This high value of salinity in the sediment indicates that the area is brackish in nature (SAWQG, 1996).

The highest concentration of phosphate was observed at Station C $(425.6 \pm 56.6 \mathrm{mg} / \mathrm{kg})$, while Station D showed the least concentration $(347.8 \pm 53.5 \mathrm{mg} / \mathrm{kg})$. The mean value of the test stations is lower than that of the control station (Table 1). In the wet season the mean value of the test station was higher than that of the control while the dry season reverse is the case, but on a general note mean phosphate concentration was higher in the dry season than in the wet season (Fig. 4). This could be due to alterations of the mechanism of phosphate in the river bed sediments as a result of activities within the area. The high level of phosphate than that of nitrates (Table 1) in the study area explains the role it plays as a nutrient for the 
growth of mangrove plants in an aquatic environment (Saravanakumar et al., 2008). Phosphates stimulate the growth of plankton and water plants that provide food for fish. This may increase the fish population and improve the waterway's quality of life. If too much phosphate is present, algae grows wildly, choke the waterway, and use up large amounts of oxygen which may ultimately lead to the death of fish and aquatic organisms. It is also an essential nutrient and another indicator of anthropogenic biological pollution (Ezekiel et al., 2011). Levels of phosphate reported in the present study are higher than that reported $(13.43 \mathrm{mg} / \mathrm{kg})$ by Ezekiel et al. (2011) from the Sombriero River sediments in the Niger Delta, Braide et al. (2004) (0.29 - $244.0 \mathrm{mg} / \mathrm{kg})$ from Miniweja stream in Rivers State and that of Babatunde and Ajibola (2009) (11.25 - 135.67 $\mathrm{mg} / \mathrm{kg}$ ) from profiles of irrigated soils.

Sulphate concentrations in the five test stations ranged between $190.0 \pm 53.0$ and 262.5 $\pm 77.8 \mathrm{mg} / \mathrm{kg}$ and the mean is $215 \pm 100.2$ $\mathrm{mg} / \mathrm{kg}$ whereas that of the control is $148.75 \pm$ $23.75 \mathrm{mg} / \mathrm{kg}$. Unlike the nitrates and phosphates (Table 1), the mean sulphates are higher in the test stations than in the control station. Chinda and Braide (2003) reported that the Niger Delta is rich in sulphate. This assertion is observed in the uniform distribution of sulphates across the stations of the study area. Sulphate is the most important form of inorganic sulphur in soils and is the most readily available form to plants because sulphates are resistant to leaching. The fate of sulphate in the sediment/soil is influenced by many chemical, biological and physical factors and the ability of the sediment/soil to absorb the sulphates occurs above a $\mathrm{pH}$ of 6.5 but adsorption increases as $\mathrm{pH}$ decreases (Cichota et al., 2004). The sulphate values of this present study is higher than that reported $(25.8 \mathrm{mg} / \mathrm{kg})$ by Ezekiel et al. (2011) from the Sombriero River sediments in the Niger Delta, that of Braide et al. (2004) (36.7 - $92.9 \mathrm{mg} / \mathrm{kg}$ ), Babatunde and Ajibola (2009) (4.7 - 16.12 $\mathrm{mg} / \mathrm{kg}$ ) from profiles of irrigated soils.

Nitrate levels in the five sampling stations fluctuate between $37.7 \pm 6.6$ (Station B) and $82.8 \pm 30.0 \mathrm{mg} / \mathrm{kg}$ (station E) while the mean is $58.0 \pm 22.9 \mathrm{mg} / \mathrm{kg}$, whereas that of the control is $76.8 \pm 15.2 \mathrm{mg} / \mathrm{kg}$. This implies a reduction in the nitrate level within the test stations for both seasons. Comparatively the wet season value is higher than that of the dry season's value; this could be due to surface water runoff into the river and gradual settlement on the riverbed sediments. Again looking at the values in Table 1 the highest values occurs down-stream of the source station towards the main Andoni River that links to the Atlantic Ocean (Fig. 1). The source (SSC) value is lower than that of the control station (SSF) hence there could have been a reduction at the source station (SSC) due to the artisanal refining activities. Nitrate, a compound of nitric acid, is the most highly oxidized form of nitrogen found in aquatic environment. It is an essential nutrient for many photosynthetic autotrophs and in some instances, functions as a growth-limiting nutrient. It is used by algae and other aquatic plants to form plant protein which, in turn, can be used by animals to form animal protein. Nitrate is a major ingredient of farm fertilizer and is necessary for plant uptake and is essential to plant growth (Helen et al., 2005). When it rains, varying nitrate amounts wash from farmland in to water body. Nitrates stimulate the growth of plankton that provides food for fish. This may increase the fish population. However, if algae grow too wildly, oxygen levels will be reduced and fish will die. Levels of $\mathrm{NO}_{3}$ reported in the present study are higher than that reported by Ezekiel $e t$ al. (2011) (3.65 mg/kg) from the Sombriero River sediments in the Niger Delta, Babatunde and Ajibola (2009) $(5.74-23.17 \mathrm{mg} / \mathrm{kg}$ ) from profiles of irrigated soils.

The range of silicate in the test stations is $190.0 \pm 53.0$ (Station D) to $262.5 \pm 77.8 \mathrm{mg} / \mathrm{kg}$ (Station A) with a mean value of $215 \pm 100.2$ $\mathrm{mg} / \mathrm{kg}$ and a control (Station F) value of 148.75 $\pm 23.75 \mathrm{mg} / \mathrm{kg}$. Comparatively the dry season's values are higher than those of the wet season (Figs. 2, 3). The silicate values were lower than the other nutrients phosphates and sulphates but higher than the nitrates. In their work from the mangroves of Kachchh-Gujarat, Saravanakumar et al. (2008) observed higher values during rainy season than in the dry season, and also higher silicate values than phosphates which are contrary in this study. The low value of silicate in the wet season may be attributed to uptake of by phytoplankton for their biological activity (Saravanakumar et al., 2008).

Chloride ion varies from $87.3 \pm 110.0$ (Station E) to $111.3 \pm 132.6 \mathrm{mg} / \mathrm{kg}$ (Station C) with an average of $97.4 \pm 89.8 \mathrm{mg} / \mathrm{kg}$ and a control value of $126 \pm 99.0 \mathrm{mg} / \mathrm{kg}$. Although there was no significant variation but the 
chloride levels are highest in Station C. The relatively high chloride value corroborates those of the conductivity and salinity values that were also high indicating the brackish status of the area (SAWQG, 1996). Unlike sulphates, chlorides are easily leached at neutral and alkaline $\mathrm{pH}$ values and hence it is not adsorbed on soil particles (Babatunde and Ajibola, 2009). At high concentrations, chlorides interact with metals to enhance corrosion by accelerating oxidation (SAWQG, 1996). As reported by Babatunde and Ajibola (2009) chloride concentrations are higher than concentrations of nitrates and sulphates in surface soils which is contrary in this study. The levels of the chlorides in the sediments are higher than that reported by Babatunde and Ajibola (2009) (35.46 - 84.22 $\mathrm{mg} / \mathrm{kg}$ ).

The total organic matter of the test stations $16.0 \pm 3.7$ and $142.2 \pm 9.6 \%$ with a mean of 45.6 $\pm 51.4 \%$ and a control value of $20.9 \pm 4.1 \%$. The level of organic matter decomposition may be attributed for the variations between the stations of the study area. Sediment is a major site for organic matter decomposition which is largely carried out by bacteria (Abowei and Sikoki, 2005). The mean value of $45.6 \pm 51.4 \%$ obtained in this study is higher than that reported by Ezekiel et al. (2011) (2.68\%) from the Sombriero river; Babatunde and Ajibola (2009) (26.0 and 18.6\%) obtained from irrigated farm soils; Sawant et al. (2011) (0.30\%) from Tapti River Maharashtra, India; Osuji and Onojake (2004) (6.2\%) from the Ebocha-8 Oil spillage site in Rivers State, Akporido and Asagba (2013) $(4.9 \pm 1.0 \%)$ from Benin river close to a lubricating oil producing factory and Saravana kumar et al. (2008) (2.56\%) from the mangroves of Kachchh-Gujarat. The activities within the present study area and the references stated above are not the same hence the higher values. The drainage scheme within the shores of the study area that houses the artisanal refining must have also drained organic matter down the river bed. It could also be due to the presence of mangrove and terrestrial detritus in the suspended matter and also due to the fine nature of sediments, high rate of sedimentation, decomposition of mangrove foliage and other vegetative remains in the sediments (Ramanathan, 1997). As reported by Saravana kumar et al. (2008) and Sawant et al. (2011) the distribution of TOC/TOM closely followed distribution of sediment type i.e., sediment low in clay content was low in TOC/TOM value and as the clay content increased, the TOC/TOM also increased. From the observations made during the field trips Station D has very fine clayish sediment than the other stations hence its high value of total organic matter, while station $\mathrm{C}$ which was a little bit sandy had the least value.

Available potassium $\left(\mathrm{K}^{+}\right)$in all the test stations ranged from $0.8 \pm 0.3$ (Station $\mathrm{B}$ ) to 1.4 $\pm 0.1 \mathrm{meq} / 100 \mathrm{~g}$ (Station A) with an average of $1.054 \pm 0.3 \mathrm{meq} / 100 \mathrm{~g}$ and a control value of $0.80 \pm 0.34 \%$.Although there were no significant differences between the stations, the mean potassium ion value of the test stations was higher than those of the control for both the wet and dry season; however, the dry season's value is higher than that of the wet season (Figs. 2, 3). $\mathrm{K}^{+}$ions are generally adsorbed onto available cation exchange sites hence their lower values.

Again they are leached very quickly out of sandy soil unlike clayish soil. For instance Station D with a high TOM recorded a relatively high $\mathrm{K}^{+}$ion value. Calcium $\left(\mathrm{Ca}^{2+}\right)$ ion in the river bed sediments varies from $0.5 \pm 0.4$ $\mathrm{meq} / 100 \mathrm{mg} / \mathrm{kg}$ (Station E) $-1.60 \pm 0.7 \mathrm{meq} / 100 \mathrm{~g}$ (Station $\mathrm{C}$ ) between the test stations with a mean value of $0.756 \pm 0.6 \mathrm{mg} / \mathrm{kg}$ and a control value of $0.261 \pm 0.13 \mathrm{meq} / 100 \mathrm{~g}$. Off all the cations $\left(\mathrm{K}^{+} \mathrm{Na}^{+}\right.$and $\left.\mathrm{Ca}^{2+}\right)$, calcium is the lowest in this present study, but comparatively the values recorded in the dry season are higher than those of the wet season. In an earlier study it was noted that $\mathrm{Ca}^{2+}$ dissolves in water column more than in the sediments, hence lower $\mathrm{Ca}^{2+}$ values. The values recorded in this study are lower than that reported (13.97-16.07 meq/100g) by Sawant et al (2011) from the Tapti River, Maharashtra, India.

Unlike the case of calcium and potassium ions, sodium ions $\left(\mathrm{Na}^{+}\right)$are high in the river bed sediments of the study area and ranges $5.3 \pm 3.9$ (Station E) to $7.9 \pm 0.5 \mathrm{meq} / 100 \mathrm{~g}$ (Station D) in the test stations with a mean value of $6.38 \pm 2.5$ $\mathrm{meq} / 100 \mathrm{~g}$ and a control value of $5.639 \pm 1.38$ meq/100g. Comparatively, the dry season's mean value is higher than that of the wet season. The reason could be due to a mixing effect of fresh water that comes into the study area from the hinterlands and the saline water that comes through the Atlantic Ocean due to tidal movements. 


\section{Conclusion}

The mean values of all the cations and total organic matter in the test stations were higher than those of the control station, however; reverse is the case with the anions apart from Chloride ion. During the wet season the mean $\mathrm{pH}$, phosphate, sulphate, nitrate and chloride ions of the control stations were all higher than those of the test stations while in the dry season the mean $\mathrm{pH}$, nitrate and chloride ions were higher in the control station than in the test station. The activities of the artisanal refining of crude oil must have affected the acidity of the study area as their $\mathrm{pH}$ values were consistently lower than that of the control station. Again because of discharge of large volume of fresh water used in their operations the conductivity of the source station was lower than other stations. While there was an increased level of phosphate in the source station, there was a reduction of Nitrate and total organic matter in the same source. However, some of the quality parameters in the river bed sediments were higher or lower than those of the control station and some related studies within and outside the region of the study area indicating some impacts which could be mostly anthropogenic. Theses impacts if not checked and the make-shift refining of the crude oil stopped could have some deleterious effects on the aquatic life quality of the ecosystem in the near future.

\section{Acknowledgments}

The authors wish to appreciate the effort by Mr. Otong Israel Clinton for his assistance during the field trips of this study and also the staff and management of Ecotech Global Resources Laboratory Port Harcourt were the analysis was carried out.

\section{References}

Abowei, J.F.N. and F.D. Sikoki 2005. Water pollution management and control, Double Trust Publications Company, Port Harcourt. $236 \mathrm{p}$.

Addo, M.A., G.M. Okley, H.A. Affum, S. Acquah, J.K. Gbadago, J.K. Senu and B.O. Botwe 2011. Water quality and level of some heavy metals in water and sediments of Kpeshie Lagoon, LaAccra, Ghana. Res. J. Environ. Earth Sci. 3(5): 487-497.

Akporido, S.O. and S.O. Asagba 2013. Quality characteristics of soil close to the Benin River in the vicinity of a lubricating oil producing factory, Koko, Nigeria. Inter. J. Soil Sci. 8(1): 1-16. DOI: 10.3923/ijss2013.

APHA, 2005. Standard methods for the examination of water and wastewater (21 $1^{\text {st }}$ ed). APHAAWNA-WPCF, American Public Health Association, New York 113.

Babatunde, O.A. and V.O. Ajibola 2009. Determination of some anions along the profile of irrigated farm soils. Environ. Res. Jou. 3(3): 101-106.

Braide, S.A., W.A.L. Izonfuo, P.U. Adakwu, A.C. Chinda and C.C. Obinwo 2004. Water quality of miniweja stream, a swamp forest stream receiving non-point source waste discharge in Eastern Niger Delta, Nigeria. Sci. Afric. 3(1): 18.

Briggs, O.A. 2010. Polycyclic aromatic hydrocarbons in selected mollusks from the tidal flats of the Sombriero River, Nigeria. Rivers State University of Science and Technology, Port Harcourt. Rivers State. Nigeria. 223p. (Ph.D. Thesis)

Chinda, A.C. and S.A. Braide 2003. Epipelic algae of tropical estuary: Case of stable and invariable seasonally community. Pol. J. Ecol. 51(1): 9199.

Cichota, R., I. Vogeler, N.S. Bolan, B. Clothier and D.R. Scotter 2004. Sulphate leaching through two contrasting New Zealand soils super soil: $3^{\text {rd }}$ Australian New Zealand Soils Conference, University of Sydney, Australia. December 5-9. pp. 1-8. www.regional.org.au/au/asssi.

Davies, O.A. and J.F.N. Abowei 2009. Sediment quality of lower reaches of Okpoka Creek, Niger Delta, Nigeria. Eur. J. Sci. Res. 26(3): 437-442.

Ebere, N. 2002. The impact of oil refinery effluents on the distribution, abundance and community structure of macro-benthos in Okrika Creek. Biology Department, Rivers State University of Science and Technology, Port Harcourt, Nigeria. (Ph.D. Thesis)

Ezekiel, E.N., A.I. Hart and J.F.N. Abowei 2011. The sediment physical and chemical characteristics in Sombreiro River, Niger Delta, Nigeria. Res. J. Environ. Earth Sci. 3(4): 341-349.

Helen, P., M. Neal, J. Alison, H. Linda and H. Wickham 2005. Water quality of treated sewage effluent in a rural area of the Upper Thames Basin, Southern England, and the impacts of such effluents on riverrine phosphorus concentrations. J. Hydrology 304(4): 103-117.

Howard, I.C. 2004. Levels and impacts of some pollutants in selected aquatic media in the Bukuma oilfield, Rivers State. Rivers State University of Science and Technology, Port Harcourt, Nigeria. 227p. (Ph.D. Thesis) 
Howard, I.C., A.O. Briggs, J.O. Nduka and N.I. Uzomba 2012. Total hydrocarbon levels of surface sediment and water from the upper reaches of Sombriero River, Niger Delta. J. Nig. Environ. Society 7(3): 16-22.

Ibigoni, C.H., U.G. Ugwemorubong Snr and M. Horsfall Jnr 2009. Evaluation of total hydrocarbon levels in some aquatic media in an oil polluted mangrove wetland in the Niger Delta. App. Ecology and Environ. Res. 7(2): 111-120. http://www.ecology.uni-corvinus.hu

Karbassi, A.R. and M. Heidari 2015. An investigation on role of salinity, $\mathrm{pH}$ and $\mathrm{DO}$ on heavy metals elimination throughout estuarial mixture. Global J. Environ. Sci. Manag. 1(1): 41-46.

Karbassi, A.R., S. Tajzihchi and S. Afshar 2015. An investigation on heavy metals in soils around oil field area. Global J. Environ. Sci. Manag. 1(4): 275-282.

Masoud, M.A., A.E.S. Elewa, A.E. Ali and E.A. Mohamed 2005. Distribution of some metal concentrations in water and sediments of lake Edeku, Egypt. Bull. Chemists Tech. Macedonia 24(1): 21-34.

Osuji, L.C. and C.M. Onojake 2004. The Ebocha-8 Oil Spillage II. Fate of associated heavy metals six months after. AJEAM-RAGEE 9: 78-87.

Osuji, L.C. and P.E. Ezebuiro 2006. Hydrocarbon contamination of a typical mangrove floor in Niger Delta, Nigeria. Int. J. Envion. Sci. Tech. 3(3): 313-320.

Ramanathan, A.L. 1997. Sediment characteristics of the Pichavaram mangrove environment, southeast coast of India. Ind. J. Mar. Sci. 26:319-322.

Saravanakumar, A., M. Rajkumar, J. Sesh Serebiah and G.A. Thivakaran 2008. Seasonal variations in physico-chemical characteristics of water, sediment and soil texture in arid zone mangroves of Kachch-Gujarat. J. Environ. Bio. 29(5): 725-732.

Sawant, C.P., R.B. Marathe and Y.V. Marathe 2011. Sediment characteristics of Tapti River, Maharashta, India. Int. J. Chem. Tech. Res. 3(3): 1179-1183.

SAWQG, 1996. Aquatic system, South African Water Quality Guidelines (1 ${ }^{\text {sted }}$ ). Department of Water Affairs and Forestry, Pretoria 0001. Republic of South Africa. Vol. 7. 145p.

UNEP, 2011. Environmental assessment of Ogoni land. United Nation Environment Programme (UNEP), Nairobi. http://postconflict.Unep.ch/ publications/OEA?UNEP_OEA.pdf 